\title{
Boomjuridischtijdschriften
}

\section{Het arrest Tjebbes: de evenredigheidstoets als complexe brug tussen nationaliteitswetgeving en Unieburgerschap}

\author{
Prof. dr. P. Van Elsuwege en H.H.C. Kroeze LL.M.
}

\author{
Aanbevolen citeerwijze bij dit artikel \\ Prof. dr. P. Van Elsuwege en H.H.C. Kroeze LL.M., 'Het arrest Tjebbes: de \\ evenredigheidstoets als complexe brug tussen nationaliteitswetgeving en \\ Unieburgerschap', NtER 2019-5-6, p.
}

De zaak Tjebbes gaat over de verenigbaarheid van een Nederlandse regeling met het Unierecht op grond waarvan tien jaar verblijf in een derde land het van rechtswege verlies van het Nederlanderschap met zich meebrengt voor Nederlanders die nog een tweede nationaliteit hebben. De zaak is daarmee een vervolg op het arrest Rottmann, waarin het Hof van Justitie bepaalde dat intrekking van de nationaliteit van de lidstaten in overeenstemming moet zijn met het Europeesrechtelijke evenredigheidsbeginsel. In Tjebbes vraagt de Raad van State of die Europeesrechtelijke evenredigheidstoets met zich meebrengt dat de gevolgen in het individuele geval moeten worden getoetst, of dat het voldoende is dat er een evenredigheidstoets in abstracto in het beleid verdisconteerd is. Anders dan advocaat-generaal Mengozzi oordeelt het Hof van Justitie dat incidenteel een geconcretiseerde evenredigheidstoets plaats moet kunnen vinden, 'vanuit het oogpunt van het Unierecht', wat betekent dat het effect van het verlies van de nationaliteit op het beroeps- en gezinsleven van de betrokkene meegewogen moet worden. Deze bijdrage evalueert deze uitspraak vanuit het perspectief van de bevoegdheidsverdeling tussen de EU en de lidstaten. Daarnaast wordt ingegaan op de beperktheid van de Unierechtelijke evenredigheidstoets zoals die in dit arrest geformuleerd wordt en worden enkele mogelijke implicaties voor de rechtspraktijk besproken. 


\section{Inleiding}

De zaak Tjebbes betreft de vraag onder welke voorwaarden een lidstaat, in dit geval Nederland, de nationaliteit van zijn onderdanen in kan trekken wanneer het verlies van de nationaliteit ook het verlies van het Unieburgerschap teweegbrengt. Hoewel

nationaliteitswetgeving tot de exclusieve bevoegdheid van de lidstaten behoort, zijn deze er immers toe gehouden deze bevoegdheid uit te oefenen met inachtneming van het Unierecht. ${ }^{\mathbf{1}}$ Reeds in de zaak Rottmann verduidelijkte het Hof van Justitie dat situaties waardoor personen door het verlies van nationaliteit van een EU-lidstaat ook het Unieburgerschap verliezen, 'wegens de aard en de gevolgen van die situatie' onder het Unierecht vallen. ${ }^{2}$ Het Hof van Justitie oordeelde vervolgens dat een beslissing om de nationaliteit van een lidstaat te ontnemen in overeenstemming moet zijn met het Europeesrechtelijke evenredigheidsbeginsel, zelfs als het op zichzelf legitiem is voor een lidstaat om de bijzondere band van solidariteit en loyaliteit tussen een staat en zijn onderdanen te bewaken. ${ }^{\mathbf{3}}$ Het Hof van Justitie liet in die zaak echter na om te specificeren of de evenredigheidstoets altijd geïndividualiseerd moet zijn, of ook in het beleid kan zijn geïntegreerd. Dit is precies de kern van de prejudiciële vragen die de Raad van State aan het Hof van Justitie heeft voorgelegd in de zaak Tjebbes. Met name wenste de Raad van State te vernemen of de evenredigheidstoets vervat kan zijn in de wettelijke regeling die voorziet in het verlies van de nationaliteit, of dat een afweging in elk individueel geval noodzakelijk is. 4

De wetgeving die in Tjebbes centraal staat, is de Rijkswet op het Nederlanderschap (RWN). Deze wet bepaalt dat een Nederlander met een tweede nationaliteit na een verblijf van tien jaar in een land buiten de EU zijn Nederlandse nationaliteit van rechtswege verliest. ${ }^{\mathbf{5}}$ De termijn kan gestuit worden wanneer de betrokkene zijn paspoort verlengt, een nationaliteitsverklaring verstrekt, ${ }^{\mathbf{6}}$ of minimaal een jaar in Nederland of in de EU woont. ${ }^{7}$ Buiten deze situaties om wordt verondersteld dat door het langdurige verblijf in een derde land de bijzondere band met Nederland is verbroken. De termijn van tien jaar waarna de betrokkene zijn Nederlanderschap verliest, vangt niet eerder aan dan op 1 april 2003.8.$^{\mathbf{8}}$ Doordat een Nederlander zijn nationaliteit in dat geval van rechtswege verliest, kan er geen geïndividualiseerde evenredigheidstoets plaatsvinden. Het Hof van Justitie gaat hier niet mee akkoord en oordeelt dat er altijd een afweging in concreto mogelijk moet zijn. Het wijkt daarmee af van de conclusie van advocaat-generaal Mengozzi, die een fundamenteel andere benadering had voorgesteld. Het arrest vormt daarom een interessante bijdrage aan de discussie omtrent de verhouding tussen het Unieburgerschap en de nationaliteitswetgeving van EU-lidstaten. ${ }^{9}$ Met name wordt verduidelijkt hoe het Unieburgerschap ingrijpt op de exclusieve bevoegdheid van de lidstaten in dit domein. Zonder te raken aan dit uitgangspunt gebruikt het Hof van Justitie de 
evenredigheidstoets om grenzen te stellen aan de autonome toepassing van de nationaliteitswetgeving. Deze evenwichtsoefening beoogt een zekere rechtsbescherming te bieden vanuit het oogpunt van het Unierecht. Desondanks blijven belangrijke vragen bestaan omtrent de precieze gevolgen van dit arrest voor de nationale rechtspraktijk en de betekenis van het Unieburgerschap als primaire hoedanigheid van de onderdanen van EU-lidstaten. ${ }^{\mathbf{1 0}}$

\section{Feiten en juridisch kader}

Het arrest Tjebbes omvat vier samengevoegde zaken. Alle betrokkenen hadden voor 1 april 2013 de Nederlandse nationaliteit én de nationaliteit van een derde staat, respectievelijk Canada, Zwitserland en Iran. Zij verblijven allen in de staat van hun andere nationaliteit. Allen werden er bij een poging tot de verlenging van hun paspoort mee geconfronteerd dat ze het Nederlanderschap waren verloren in het voorjaar van 2013. Saleh Abady (Iranees/Nederlands), Tjebbes (Canadees/Nederlands) en Koopman (Zwitsers/Nederlands) hebben hun nationaliteit verloren omdat ze sinds 1 april 2003 langer dan tien jaar in het buitenland hebben gewoond en in die periode geen actie hebben ondernemen om het verlies van hun Nederlanderschap te voorkomen. ${ }^{\mathbf{1 1}}$ Duboux is de dochter van Koopman en stond in het paspoort van haar moeder bijgeschreven. Zij heeft de Nederlandse nationaliteit verloren, omdat haar moeder vanaf 1 april 2013 geen Nederlandse meer was. ${ }^{\mathbf{1 2}}$ Geen van de betrokkenen was zich ervan bewust dat zij de Nederlandse nationaliteit hadden verloren totdat zij een nieuw paspoort aanvroegen, dat geweigerd werd omdat zij het Nederlanderschap verloren hadden. ${ }^{\mathbf{3}}$

Ervan uitgaande dat het verlies van de nationaliteit van rechtswege, net als het verlies van de nationaliteit door een individueel besluit, zoals in Rottmann het geval was, in overeenstemming moet zijn met het Europeesrechtelijk evenredigheidsbeginsel, vraagt de Raad van State het Hof van Justitie of deze evenredigheidstoetsing besloten kan liggen in een algemene wettelijke regeling zelf of dat daarvoor steeds een individuele toetsing plaats moet vinden en of de Nederlandse regeling aan de daaraan gestelde voorwaarden voldoet. In het bijzonder vraagt de Raad van State of de regeling wat betreft de positie van minderjarige kinderen in overeenstemming is met de verplichting voor de lidstaten om het belang van het kind steeds voorop te stellen (art. 24 lid 2 en 3 Handvest). De wetgever heeft voor hen het belang van de eenheid van nationaliteit in een gezin laten prevaleren boven het individuele behoud van de Nederlandse nationaliteit. Om die reden brengt het verlies van de nationaliteit door een ouder automatisch ook het verlies van die nationaliteit van het kind teweeg, zonder de mogelijkheid om dat verlies te stuiten, zoals dat voor een volwassene wel kan. ${ }^{\mathbf{1 4}}$ 
Advocaat-generaal Mengozzi is bovenal voorzichtig om niet te ver in te grijpen in de nationale bevoegdheid van de lidstaten om de voorwaarden voor verkrijging en verlies van hun nationaliteit te bepalen. ${ }^{\mathbf{1 5}}$ Hij neemt het 'internationaalrechtelijke beginsel dat niemand willekeurig zijn nationaliteit mag worden ontnomen' als uitgangspunt. ${ }^{\mathbf{1 6}}$ Intrekking van nationaliteit is niet onmogelijk, maar moet een beschermenswaardig doel nastreven. In Rottmann heeft het Hof van Justitie geoordeeld dat de bescherming van 'de bijzondere band van solidariteit en loyaliteit' tussen een lidstaat en zijn onderdanen hieronder valt. ${ }^{17}$ Deze conclusie stemt overeen met artikel 1 sub e van het Europees Verdrag inzake nationaliteit, dat bepaalt dat een staat niet mag voorzien in het verlies van de nationaliteit van rechtswege, tenzij de effectieve band die een staat gewoonlijk met zijn onderdanen verbindt, ontbreekt. De doelstelling van de Rijkswet op het Nederlanderschap om te voorkomen dat onderdanen die al heel lang in het buitenland wonen de Nederlandse nationaliteit behouden terwijl zij geen band meer hebben met Nederland is op basis van dit verdrag een geoorloofd streven. ${ }^{\mathbf{8}}$ Europeesrechtelijk vereist de intrekking van nationaliteit dat het besluit hiertoe evenredig is en rekening houdt met de gevolgen van het verlies van het Unieburgerschap en de daaraan verbonden rechten voor de betrokkene en zijn gezinsleden. ${ }^{\mathbf{1 9}}$ Volgens advocaat-generaal Mengozzi kan de evenredigheidstoets in abstracto worden uitgevoerd zonder dat er per geval een geïndividualiseerde evenredigheidstoets nodig is. Een algemene toetsing aan de doelstelling en invulling van de wettelijke regeling is in dat geval voldoende om aan de Unierechtelijke evenredigheidsvereiste te voldoen. ${ }^{\mathbf{2 0}}$ Deze conclusie zou onder andere volgen uit de analoge toepassing van het arrest Delvigne, waarin een nationale regeling die met zich meebracht dat Unieburgers bij de veroordeling voor een strafbaar feit automatisch en zonder individuele toetsing hun stemrecht voor het Europees Parlement kwijtraakten geoorloofd was. ${ }^{\mathbf{2 1}}$ De toetsing van de nationale maatregel aan het evenredigheidsbeginsel moet in dat geval beperkt blijven tot de vraag of de maatregel geschikt en noodzakelijk is om het gestelde doel te dienen, zonder dat daarbij op de persoonlijke omstandigheden van de betrokkene hoeft te worden ingegaan. ${ }^{22}$

Met betrekking tot de Rijkswet op het Nederlanderschap wijst Mengozzi er onder andere op dat het 'vrij eenvoudig is' om de tien jaar-termijn waarna het Nederlanderschap verloren raakt te stuiten door een paspoort aan te vragen of een verklaring omtrent het Nederlanderschap af te geven. ${ }^{\mathbf{2 3}}$ Het lijkt hem voorts 'geenszins onredelijk en onevenredig' om van een onderdaan die woonachtig is in een derde land te verlangen dat hij zijn papieren verlengt als voorwaarde voor het behoud van het Nederlanderschap. ${ }^{\mathbf{2 4}}$ Daarnaast overweegt hij dat het verlies van het Nederlanderschap niet onomkeerbaar is en opnieuw verkregen kan worden tegen gunstigere voorwaarden dan de voorwaarden die gelden voor een persoon die de nationaliteit nooit heeft bezeten. ${ }^{\mathbf{2 5}} \mathrm{Hij}$ concludeert daarom dat artikel 
15 lid 1 sub c RWN niet in strijd is met het Unierechtelijke evenredigheidsbeginsel. ${ }^{\mathbf{2 6}}$ Voorts beargumenteert hij dat het aan de nationale wetgever is om te bepalen welke omstandigheden meegewogen moeten worden in de beoordeling of een effectieve band tussen de lidstaat en het individu bestaat, zodat het niet in acht nemen van door de betrokkene aangevoerde omstandigheden niet afdoet aan de evenredigheid van de intrekking. ${ }^{27}$ Het toepassen van een geïndividualiseerde evenredigheidstoets brengt volgens hem een risico op willekeur met zich mee. Mocht er toch een geïndividualiseerde evenredigheidstoets worden vereist, dan verzoekt de advocaatgeneraal het Hof van Justitie om in dat geval concreet aan te geven 'welke criteria voor verbondenheid met de betrokken lidstaat relevant zijn'. ${ }^{28}$

Wat betreft de evenredigheid van artikel 16 lid 1 sub d RWN op basis waarvan kinderen wanneer hun ouder(s) de Nederlandse nationaliteit verliezen hun nationaliteit ook van rechtswege kwijt zijn, komt de advocaat-generaal tot een andere conclusie. Hij vindt het onder andere bezwaarlijk dat 'de Nederlandse wetgever ervan is uitgegaan dat de eenheid van nationaliteit binnen het gezin altijd samenvalt met het belang van het kind, behalve in de door die wetgever zelf erkende uitzonderingsgevallen' en dat kinderen daarom niet dezelfde mogelijkheden hebben om dit verlies te stuiten als volwassenen. ${ }^{\mathbf{2 9}} \mathrm{Het}$ autonome karakter van het Unieburgerschap vereist echter dat zij minimaal dezelfde procedurele en materiële rechten zouden moeten hebben als meerderjarigen. ${ }^{\mathbf{3 0}}$ Daarom is het volgens de advocaatgeneraal noodzakelijk dat de regeling in een uitzondering voorziet op grond waarvan het kind zijn nationaliteit niet verliest wanneer dit niet in zijn belang is, zelfs als zijn ouder die nationaliteit wel verliest. Die mogelijkheid bestaat echter niet, zodat de nationale regeling verder gaat dan noodzakelijk is om het beoogde doel te bereiken. ${ }^{\mathbf{3 1}}$

\section{Uitspraak van het Hof van Justitie}

Net als de advocaat-generaal erkent het Hof van Justitie de rechtmatigheid van het belang van een lidstaat om 'de bijzondere band van solidariteit en loyaliteit tussen hem en zijn onderdanen' te beschermen. ${ }^{\mathbf{3 2}}$ Het ontbreken van een dergelijke effectieve band is daarom een legitieme reden om een individu de nationaliteit te ontnemen. Het criterium van tien jaar ononderbroken verblijf in het buitenland is geschikt om die effectieve band te toetsen. Volgens het Hof van Justitie is het 'eveneens rechtmatig dat een lidstaat de eenheid van nationaliteit binnen een en hetzelfde gezin wil beschermen' en is het legitiem om aan te nemen dat het ontbreken van een effectieve band tussen de ouders en Nederland in beginsel ook impliceert dat die band ontbreekt tussen de minderjarige en die lidstaat. ${ }^{33}$ Het Hof van Justitie oordeelt daarom dat de Nederlandse wetgeving in overeenstemming is met het internationaal recht, en in het bijzonder met artikel 7 van het Nationaliteitsverdrag dat voorziet 
in de gronden voor verlies van nationaliteit die de Nederlandse wet toepast (gebrek aan effectieve band en verlies van de nationaliteit door een ouder). Noch ontstaat er een probleem met de verplichtingen die voortvloeien uit het Staatloosheidsverdrag, omdat het verlies van nationaliteit zich alleen voordoet als de betrokkene nog een tweede nationaliteit heeft en dus niet staatloos zal worden. ${ }^{\mathbf{3 4}}$ Het feit dat het verlies van de nationaliteit gemakkelijk te stuiten is door een paspoort of een identiteitskaart aan te vragen of door een verklaring omtrent het Nederlanderschap te verstrekken draagt eveneens bij aan de rechtmatigheid van de regeling. Anders dan de advocaat-generaal verklaart het Hof van Justitie daarom dat de gehele regeling, inclusief het verlies van de nationaliteit door een minderjarige wanneer zijn ouder de nationaliteit verliest, in beginsel rechtmatig is. Daar staat tegenover dat het Hof van Justitie concludeert dat de

Europeesrechtelijke evenredigheidstoets waaraan de intrekking van de nationaliteit van een individu moet voldoen wel degelijk vereist dat de mogelijkheid bestaat om de gevolgen verbonden aan het verlies van het Unieburgerschap voor de betrokken personen in het individuele geval te toetsen. 35 De nationale autoriteiten moeten daarom incidenteel kunnen onderzoeken welke gevolgen het nationaliteitsverlies met zich meebrengt en ervoor zorgen dat in voorkomend geval de nationaliteit met terugwerkende kracht opnieuw toegekend kan worden. ${ }^{\mathbf{3 6}}$ Dat onderzoek vereist dat de individuele situatie van de betrokkene en zijn gezin worden beoordeeld wat betreft de gevolgen van de intrekking van de nationaliteit voor de normale ontwikkeling van het gezins- en beroepsleven en de door het Handvest gewaarborgde grondrechten, in het bijzonder de eerbiediging van het familie- en gezinsleven (art. 7 Handvest) en het belang van het kind (art. 24 lid 2 Handvest). 37

Omstandigheden waarmee rekening gehouden moet worden zijn onder meer het feit dat de Unieburger

'zou kunnen worden geconfronteerd met beperkingen in de uitoefening van zijn recht van vrij verkeer (...) wat in voorkomend geval leidt tot bijzondere moeilijkheden om zich naar Nederland of een andere lidstaat te blijven begeven teneinde daadwerkelijke en regelmatige banden met gezinsleden te onderhouden dan wel aldaar zijn beroepsactiviteiten te verrichten of de noodzakelijke stappen te ondernemen om er dergelijke activiteiten te verrichten'.

Eveneens relevant is het feit

'dat de betrokkene mogelijkerwijs geen afstand kon doen van de nationaliteit van een derde staat (...) en ten tweede dat het ernstige risico dat zijn veiligheid of zijn vrijheid om te gaan en staan waar hij wil aanzienlijk zou afnemen, aan welk risico de betrokkene zou blootstaan omdat hij op het grondgebied van de derde staat waar hij verblijft, niet de consulaire bescherming' 
van het Unierecht zou genieten. $\mathbf{3}^{\mathbf{8}}$

\section{Commentaar}

\section{Bevoegdheidsverdeling tussen de EU en de lidstaten}

Er bestaat een zeker spanningsveld tussen de nationaliteitswetgeving van EU-lidstaten en de verdragsbepalingen omtrent het Unieburgerschap. Enerzijds behoort het nationaliteitsrecht tot het exclusieve bevoegdheidsdomein van de lidstaten waardoor elke lidstaat zelf de voorwaarden voor de verkrijging en het verlies van de nationaliteit kan bepalen. ${ }^{39}$ Anderzijds volgt uit artikel 20 lid 1 Verdrag betreffende de Werking van de Europese Unie (VWEU) dat eenieder die de nationaliteit van een lidstaat bezit ook burger van de Unie is. Volgens vaste rechtspraak van het Hof van Justitie moet het Unieburgerschap 'de primaire hoedanigheid van de onderdanen van de lidstaten' zijn. ${ }^{40}$ Aangezien de aan deze status verbonden rechten voortvloeien uit het Unierecht, heeft elke aanpassing aan de nationaliteitswetgeving van een lidstaat onvermijdelijk een Unierechtelijke dimensie. ${ }^{\mathbf{4 1}}$

Dit spanningsveld tussen nationaliteitswetgeving en het Unierecht is allesbehalve nieuw. Reeds in de zaak Micheletti uit 1992 oordeelde het Hof van Justitie dat lidstaten hun exclusieve bevoegdheid inzake nationaliteitsrecht moeten uitoefenen met inachtneming van hun Europeesrechtelijke verplichtingen. ${ }^{\mathbf{4 2}}$ In het meer recente arrest Rottmann verduidelijkte het Hof van Justitie bovendien dat een nationaalrechtelijke beslissing tot intrekking van nationaliteit die leidt tot het verlies van het Unieburgerschap 'wegens de aard en gevolgen ervan' onder het Unierecht valt. ${ }^{43}$ De zaak Tjebbes bouwt verder op deze logica en bevestigt dat het nationaliteitsrecht van lidstaten vatbaar is voor rechterlijke toetsing aan het Unierecht.

De cruciale vraag is echter hoe deze rechterlijke toetsing kan worden ingevuld zonder al te sterk in te grijpen op de bevoegdheidsverdeling tussen de EU en haar lidstaten. Deze bezorgdheid wordt expliciet geuit door advocaat-generaal Mengozzi, die er onder andere op wijst dat de Unie ertoe gehouden is de nationale identiteit van de lidstaten te respecteren, zoals vastgelegd in artikel 4 lid 2 VEU. Hij is van oordeel dat een geïndividualiseerde evenredigheidstoets afbreuk doet aan de bevoegdheid van de nationale wetgever en bovendien rechtsonzekerheid creëert (zie supra). ${ }^{\mathbf{4}}$ Hoewel het Hof van Justitie zijn advies om daarom enkel een evenredigheidstoets in abstracto toe te passen negeert, weerspiegelt de manier waarop de rechterlijke toetsing wordt ingevuld heel sterk de bevoegdheidsverdeling tussen de EU en de lidstaten. Daarnaast lijkt het Hof van Justitie gehoor te geven aan het verzoek van de advocaat-generaal om concrete criteria te geven aan de hand waarvan de evenredigheidstoets moet worden uitgevoerd. ${ }^{45}$ Het vertrekpunt is en blijft dat de lidstaten zelf instaan voor de invulling van de voorwaarden voor de verkrijging en het 
verlies van nationaliteit. Op dit punt beperkt de juridische controle zich in eerste instantie tot het internationaal publiekrecht. De definitie van nationaliteit als de uitdrukking van een 'effectieve band' tussen een staat en zijn onderdanen die door het Hof van Justitie wordt gehanteerd, is geïnspireerd door de Nottebohm-doctrine ${ }^{\mathbf{4 6}}$ en de Nederlandse invulling hiervan wordt getoetst aan het Verdrag inzake de beperking van staatsloosheid en het Europees

Nationaliteitsverdrag. ${ }^{47}$ Pas in tweede instantie, en enkel en alleen met betrekking tot de gevolgen van de beslissing tot het intrekken van de nationaliteit, speelt het Unierecht een rol. In navolging van het arrest Rottmann zijn de nationale autoriteiten en de nationale rechterlijke instanties immers gehouden aan een evenredigheidstoets 'vanuit het oogpunt van het Unierecht'. ${ }^{88}$ Dit impliceert dat het besluit tot intrekking van de nationaliteit rekening moet houden met de gevolgen van het verlies van de aan het Unieburgerschap verbonden rechten zoals het recht op vrij verkeer en verblijf op het grondgebied van de lidstaten en het recht op consulaire bescherming.

De Unierechtelijke evenredigheidstoets vormt met andere woorden de brug tussen de exclusieve lidstaatbevoegdheid inzake nationaliteitswetgeving enerzijds en het Unieburgerschap als de primaire hoedanigheid van de onderdanen van lidstaten anderzijds. Met deze oplossing poogt het Hof van Justitie derhalve de bevoegdheidsverdeling tussen de Unie en de lidstaten, vastgelegd in artikel 4 lid 1 jo. 5 lid 1 en 2 VEU, te verzoenen met de rechten die op basis van het Unierecht aan onderdanen van de lidstaten worden toegekend op basis van artikel 20 VWEU. Deze evenwichtsoefening is complex en de benadering die het Hof van Justitie gekozen heeft, is niet zonder kritiek. Enerzijds kan worden beargumenteerd dat het Hof van Justitie slechts lippendienst bewijst aan de stelling dat het Unieburgerschap de primaire hoedanigheid van de onderdanen van de lidstaten moet zijn. ${ }^{49}$ Anderzijds grijpt de uitspraak van het Hof van Justitie wel degelijk in op de exclusieve bevoegdheid van lidstaten inzake nationaliteitswetgeving, zonder dat de verdragen in die zin werden aangepast..$^{\mathbf{0}}$ Het arrest kan dus zowel geïnterpreteerd worden als een stap terug inzake de ontwikkeling van een autonoom Unieburgerschap of als een (te) verregaande inmenging in lidstaataangelegenheden. De waarheid ligt allicht in het midden, in de zin dat het Hof van Justitie beoogt om de aan het Unieburgerschap verbonden rechten te beschermen zonder voorbij te gaan aan de bevoegdheid van lidstaten door terug te grijpen naar het mechanisme van de proportionaliteit. Hoewel deze oplossing logisch lijkt in het licht van eerdere rechtspraak, in het bijzonder Rottmann, leidt het ook tot nieuwe problemen in de praktijk. Met name de precieze invulling van de evenredigheidstoets is nog steeds onderwerp van discussie.

\section{Evenredigheidstoets 'vanuit het oogpunt van het Unierecht'}

Het arrest Tjebbes verduidelijkt dat de evenredigheidstoets bij de 
intrekking van de nationaliteit van een lidstaat geïndividualiseerd moet kunnen zijn. Het Hof van Justitie lijkt hiermee grotendeels voorbij te gaan aan de zorgen van advocaat-generaal Mengozzi aangaande de impact van een geïndividualiseerde evenredigheidstoets op de bevoegdheidsverdeling tussen de EU en de lidstaten en over het risico op willekeur dat een geïndividualiseerde toets met zich mee zou brengen (zie supra). ${ }^{\mathbf{5 1}}$ Uit een nadere beschouwing van de door het Hof van Justitie opgelegde toets blijk echter dat wel degelijk rekening is gehouden met de waarschuwingen van de advocaat-generaal. Het arrest lijkt daar impliciet een antwoord op te zijn.

Het is opmerkelijk dat de evenredigheidstoetsing alleen de gevolgen 'uit het oogpunt van het Unierecht' hoeft te betrekken. ${ }^{\mathbf{2}}$ Dit impliceert dat andere overwegingen, zoals het gebrek aan kennisgeving van de nieuwe wetgeving aan de betrokkenen of het feit dat de betrokkenen al dan niet het Nederlands beheersen, buiten beschouwing worden gelaten. De toets betreft immers enkel de gevolgen van het verlies aan Unieburgerschap en de daaraan verbonden rechten. Het Hof van Justitie wijst daarbij alleen op gevolgen voor mogelijke beroepsverrichtingen en/of het familieleven en voor de mogelijkheid om een beroep te doen op consulaire bescherming. 53 De geïndividualiseerde evenredigheidstoets wordt door die beperktheid aanzienlijk in impact gereduceerd, en daarmee de betekenis van het Unieburgerschap zelf, dat blijkbaar alleen van belang is voor de instandhouding van het beroeps- en gezinsleven in de EU. Deze materiële beperking van de evenredigheidstoets is in overeenstemming met de bevoegdheidsverdeling tussen de lidstaten en de EU in die zin dat alleen aspecten van het burgerschap die door de EU gereguleerd worden in acht moeten worden genomen. Het Unieburgerschap garandeert immers het recht om in alle lidstaten beroepsleven op te bouwen en uit te oefenen, waarvoor het recht op de uitoefening van het familieleven ondersteunend is. ${ }^{\mathbf{5 4}}$ Daarnaast komt het Hof van Justitie met de instructies tegemoet aan het verzoek van de advocaat-generaal om concrete criteria te geven aan de hand waarvan een eventuele geïndividualiseerde evenredigheidstoets moet worden ingevuld. $\mathbf{5 5}$

Het nadeel van de manier waarop het Hof van Justitie de evenredigheidstoets vormgeeft, is dat de toetsing erg nauw is. Het Hof van Justitie besteedt bijvoorbeeld in het geheel geen aandacht aan het verlies van sociale of politieke rechten, terwijl die rechten ook aan het Unieburgerschap verbonden zijn. Deze selectiviteit van het Hof van Justitie in het niveau waarop burgerrechten beschermd worden is ook in bredere zin terug te zien in de rechtspraak. Recente jurisprudentie over sociale zekerheid is bekritiseerd omdat het Hof van Justitie oordeelde dat een geïndividualiseerde evenredigheidstoets bij de ontzegging van sociale rechten overbodig was. ${ }^{\mathbf{5 6}}$ In een arrest dat ging over de aanspraak van een Zweedse onderdaan op een werkloosheidsuitkering in Duitsland oordeelde het Hof van Justitie bijvoorbeeld dat 'een dergelijk individueel onderzoek (...) in een 
situatie als die van het hoofdgeding niet geboden' was. ${ }^{\mathbf{5 7}}$ Een vergelijkbare conclusie kan afgeleid worden uit het arrest Delvigne, waarin een Franse regeling ter discussie stond op grond waarvan een strafrechtelijke veroordeling verlies van het stemrecht voor het Europees Parlement teweegbracht..$^{\mathbf{5}}$ Het Hof van Justitie oordeelde dat deze situatie verenigbaar was met het Unierechtelijke evenredigheidsbeginsel, omdat in de regeling zelf rekening werd gehouden met de aard en de ernst van het strafbare feit en met de duur van de opgelegde straf en omdat een betrokkene de mogelijkheid heeft om zijn stemrecht weer terug te krijgen. ${ }^{59}$ Het feit dat de regeling de gevolgen van het verlies van het stemrecht voor het individu niet meewoog, deed daar niet aan af. In zijn conclusie in de zaak Tjebbes overwoog advocaat-generaal Mengozzi daarom dat uit Delvigne af te leiden valt dat het Unierechtelijke evenredigheidsbeginsel niet vereist dat de individuele omstandigheden in acht worden genomen. ${ }^{\mathbf{6 0}}$ Daarentegen blijkt uit vaste rechtspraak dat de beperking van het verblijfsrecht van EUburgers en hun familieleden op het grondgebied van de lidstaten van de EU wel expliciet vereist dat er rekening wordt gehouden met de individuele omstandigheden van het geval. ${ }^{\mathbf{6 1}}$ Het Hof van Justitie lijkt sommige burgerrechten dus te verkiezen boven andere. Kan daaruit worden afgeleid dat die burgerrechten minder relevant zijn, zodat het verlies van die rechten in voorkomend geval niet meegewogen hoeven te worden in de evenredigheidstoets? Of kan het verschil in dit geval, in de zaak Tjebbes, wellicht verklaard worden door het feit dat EUburgers die in het buitenland wonen per definitie niet noodzakelijk dezelfde sociale en politieke rechten hebben als EU-burgers die in hun eigen staat verblijven? Bij migratie binnen de EU worden bepaalde sociale en politieke rechten weliswaar behouden, maar bij vertrek naar een derde land staat het de lidstaat vrij om aanspraken op sociale zekerheid en de uitoefening van politieke rechten te laten behouden of onmogelijk te maken. Deze benadering verklaart wellicht ook waarom het Hof van Justitie in de evenredigheidstoets wel nog betrekt of het verlies van de nationaliteit een ernstig risico met zich mee kan meebrengen voor de veiligheid of vrijheid van de betrokkene wanneer deze door het verlies van het Unieburgerschap geen aanspraak meer heeft op consulaire bescherming op grond van artikel 20 lid 2 sub c VWEU. ${ }^{62}$ Dat recht bestaat immers bij uitstek wél bij verblijf in een derde land.

De specifieke Europeesrechtelijke inkleding van de evenredigheidstoets betekent eveneens dat er een zekere ongelijkheid ontstaat die lijkt op een vorm van omgekeerde discriminatie. Omgekeerde discriminatie houdt in dat EU-burgers die altijd in de lidstaat van hun nationaliteit verbleven hebben en die onder het nationale recht van die lidstaat vallen zich juridisch in een slechtere positie bevinden dan EU-burgers die gebruik hebben gemaakt van de rechten die aan het Unieburgerschap verbonden zijn en die daarom onder het EU-recht vallen. ${ }^{\mathbf{6 3}}$ Uit het arrest Tjebbes volgt eenzelfde 
principe. EU-burgers die aanspraak maken op bescherming van hun beroeps- of familieleven onder het EU-recht genieten meer bescherming tegen de intrekking van hun nationaliteit dan EUburgers die geen beroeps- of familieleven in een EU-context hebben opgebouwd. Zij kunnen even sterke bezwaren hebben tegen de intrekking van hun nationaliteit als degenen die wel onder het EUrecht vallen, maar slechts omdat de EU-rechtelijke dimensie ontbreekt, geldt voor hen niet dezelfde standaard waaraan moet worden voldaan vooraleer de nationaliteit ingetrokken mag worden. In het licht van de bevoegdheidsverdeling is een dergelijk onderscheid wellicht onontkoombaar. De nationale wetgever zou er echter goed aan doen om de evenredigheidstoets die Tjebbes voorschrijft een bredere invulling te geven dan Europeesrechtelijk strikt genomen zou moeten. Een zo gelijk mogelijke behandeling van iedereen die onevenredig benadeeld wordt door de intrekking van het Nederlanderschap is nastrevenswaardig, ongeacht of het gaat om benadeling in de rechten die voortvloeien uit het Unieburgerschap of anderszins.

\section{Aard van de toets - procedureel of imperatief?}

Naast de vraag welke elementen in de evenredigheidstoets meegewogen moeten worden, is ook de precieze aard van deze toets nog niet geheel duidelijk. Het Hof van Justitie oordeelt dat de absolute onmogelijkheid tot een geïndividualiseerde toets strijdig is met het Unierecht. ${ }^{64}$ De autoriteiten moeten daarom incidenteel kunnen onderzoeken welke gevolgen het nationaliteitsverlies in een concreet geval met zich meebrengt 'wanneer [de EU-burger] een aanvraag indient voor een reisdocument'. ${ }^{\mathbf{5}}$ Het woord 'incidenteel' suggereert dat deze geïndividualiseerde evenredigheidstoetsing niet systematisch hoeft te zijn, maar slechts plaats hoeft te vinden op verzoek van de betrokkene wanneer hij een nieuw reisdocument aanvraagt. Er wordt dus een actief handelen van het individu verwacht voordat die toetsing plaats hoeft te vinden. De vraag die dit oproept, en waar het arrest Tjebbes geen antwoord op geeft, is hoe lang na de intrekking van het Nederlanderschap het individu nog kan vragen om die 'incidentele' geïndividualiseerde evenredigheidstoetsing. Moet dit een korte periode zijn die slechts gereserveerd is voor mensen die de termijn voor het aanvragen van een paspoort verschoonbaar overschrijden? Moet dit in de vorm van een expliciete beslissing over de intrekking van het Nederlanderschap waartegen beroep ingesteld kan worden? Of kan een individu nog in de lengte der dagen verzoeken om een individuele toetsing wanneer hij er pas veel later achter komt dat hij zijn Nederlanderschap überhaupt verloren heeft? In het verlengde daarvan volgt bovendien de vraag ten aanzien van welk moment in de tijd de evenredigheidstoetsing moet plaatsvinden. Moet het besluit evenredig zijn op het moment van intrekking van de nationaliteit? Of moet getoetst worden of de intrekking (nog steeds) evenredig is op het 
moment dat de Nederlander vraagt om de (incidentele)

geïndividualiseerde toetsing?

Nog weer een andere vraag is hoeveel discretionaire ruimte de lidstaten behouden om in een individueel geval het belang van de staat te laten prevaleren. Als iemand familieleven in de EU onderhoudt, maar de Amerikaanse nationaliteit heeft, mag de Nederlandse staat dan beargumenteren dat je met de Amerikaanse nationaliteit visumvrij naar Nederland kunt reizen en dat de intrekking daarom desalniettemin evenredig is? Of heeft het eenvoudige feit dat het gezins- of beroepsleven van een individu wordt beïnvloed automatisch tot gevolg dat hij de Nederlandse nationaliteit mag behouden? Een aanwijzing kan wellicht gevonden worden in het gebruik van de woorden 'bijzondere moeilijkheid'. Hieruit blijkt dat een enkel effect van het verlies van de nationaliteit op het gezins- of beroepsleven van het individu kennelijk onvoldoende is om de maatregel onevenredig te laten zijn. Er moet sprake zijn van een bijzondere moeilijkheid voordat het effect van de intrekking tot gevolg kan hebben dat de intrekking als geheel onevenredig is. Daarnaast stelt het Hof van Justitie dat geen rekening moet worden gehouden met hypothetische gevolgen of gevolgen waarvan niet vaststaat dat zij zich zullen voordoen. ${ }^{66}$ Deze toevoeging lijkt eveneens aan te geven dat de nationale autoriteiten een marge behouden bij de concrete toepassing van de evenredigheidstoets. Het mogelijk gevolg is dat de Unierechtelijke evenredigheidstoets op basis van het arrest Tjebbes voornamelijk een procedurele verplichting aan de lidstaten oplegt. In dat geval kan het beleid volledig in stand blijven, met als minimalistische aanpassing dat de lidstaat incidenteel motiveert waarom de beslissing in het individuele geval evenredig is. Het is dan uiteindelijk aan de nationale rechter om te beoordelen of die motivering de evenredigheidstoets doorstaat, rekening houdende met de algemene criteria die door het Hof van Justitie werden aangereikt.

\section{Conclusie}

Met het arrest Tjebbes bouwt het Hof van Justitie verder op eerdere rechtspraak omtrent de verhouding tussen de nationaliteitswetgeving van lidstaten en het burgerschap van de Unie. In navolging van de beslissing in Rottmann bevestigt het Hof van Justitie dat de intrekking van nationaliteit door een lidstaat die leidt tot het verlies aan Unieburgerschap in overeenstemming moet zijn met het Unierechtelijk evenredigheidsbeginsel. In Tjebbes geeft het Hof van Justitie hiervoor concretere richtlijnen, zoals de noodzaak om rekening te houden met de individuele situatie van de betrokkene. In het licht van de bevoegdheidsverdeling tussen de EU en haar lidstaten beperkt de Unierechtelijke evenredigheidstoets zich tot een onderzoek naar de gevolgen van het verlies van het Unieburgerschap en de daaraan verbonden rechten.

Ondanks de aanwijzingen omtrent de omstandigheden die relevant 
kunnen zijn bij toepassing van deze toets, zoals de mogelijke beperkingen inzake de uitoefening van het recht op vrij verkeer en gevolgen daarvan voor de normale ontwikkeling van het gezins- en beroepsleven, blijft de concrete invulling van de evenredigheidstoets nog voor verheldering vatbaar. Het is bijvoorbeeld onduidelijk waarom het Hof van Justitie het verlies van politieke en sociale rechten die aan het Unieburgerschap verbonden zijn niet in de evenredigheidstoets betrekt. Noch is het duidelijk wanneer er precies sprake is van 'bijzondere moeilijkheden' in de ontwikkeling van het gezins- en beroepsleven. Deze onduidelijkheid brengt onzekerheid en mogelijk ook ongelijkheid teweeg tussen EU-burgers voor wie intrekking om verschillende redenen onevenredig kan zijn.

Tegelijkertijd lijkt deze onzekerheid inherent te zijn aan de toepassing van een geïndividualiseerde evenredigheidstoets. Het is de haast onvermijdelijke prijs in de evenwichtsoefening tussen het respect voor de soevereine beleidskeuzes van EU-lidstaten inzake nationaliteitsrecht enerzijds en een minimale rechtsbescherming op basis van het Unieburgerschap anderzijds.

\section{Noten}

1 HvJ 7 juli 1992, zaak C-369/70, Micheletti, ECLI:EU:C:1992:295, punt 10; HvJ 20 februari 2001, zaak C-192/99, Kaur, ECLI:EU:C:2001:106, punt 19.

2 HvJ 2 maart 2010, zaak C-135/o8, Rottmann, ECLI:EU:C:2010:104, punt 39-41; HvJ 12 maart 2019, zaak C-221/17, Tjebbes e.a./Minister van Buitenlandse Zaken, ECLI:EU:C:2019:189, punt 30.

3 Rottmann, punt 51.

4 Tjebbes, punt 21.

5 Art. 15 lid 1 sub c Rijkswet op het Nederlanderschap (RWN).

6 Art. 15 lid 3 RWN.

7 Art. 15 lid 1 sub c en lid 4 RWN.

8 Art. IV van de Rijkswet van 21 december 2000 tot wijziging van de Rijkswet op het Nederlanderschap met betrekking tot de verkrijging, de verlening en het verlies van het Nederlanderschap; conclusie A-G Mengozzi 12 juli 2018, zaak C-221/17, Tjebbes, ECLI:EU:C:2018:572, punt 7 .

9 Zie o.a. omtrent deze discussie: S. O'Leary, 'Nationality Law and Community Citizenship: A Tale of Two Uneasy Bedfellows', Yearbook of European Law 1992, p. 353-384; H. Oosterom-Staples, 'The 
Triangular Relationship between Nationality, EU Citizenship and Migration in EU Law: A Tale of Competing Competences', Netherlands International Law Review 2018, p. 431-461.

10 HvJ 20 september 2001, zaak C-184/99, Grzelczyk, ECLI:EU:C:2001:458, punt 31.

11 Art. 15 lid 1 sub c jo. art. 15 lid 3 en 4 RWN.

12 Ingevolge art. 16 lid 1 sub d RWN.

13 Conclusie A-G Mengozzi, Tjebbes, punt 5-14; Tjebbes, punt 13-19.

14 Conclusie A-G Mengozzi, Tjebbes, punt 15-21; Tjebbes, punt 20-26.

15 S. Coutts, 'Bold and Thoughtful: The Court of Justice intervenes in nationality law Case C-221/17 Tjebbes' European Law Blog, 25 March 2019.

16 Conclusie A-G Mengozzi, Tjebbes, punt 48.

17 Conclusie A-G Mengozzi, Tjebbes, punt 48; Rottmann, punt 50-54.

18 Conclusie A-G Mengozzi, Tjebbes, punt 51-59.

19 Conclusie A-G Mengozzi, Tjebbes, punt 49; Rottmann, punt 55-56.

20 Conclusie A-G Mengozzi, Tjebbes, punt 60-91, vooral punt 60-63.

21 HvJ 6 oktober 2015, zaak C-650/13, Delvigne, ECLI:EU:C:2015:648; conclusie A-G Mengozzi, Tjebbes, punt 64-67.

22 Conclusie A-G Mengozzi, Tjebbes, punt 82, 91.

23 Conclusie A-G Mengozzi, Tjebbes, punt 92-96.

24 Conclusie A-G Mengozzi, Tjebbes, punt 96-97.

25 Art. 6 lid 1 sub f RWN; conclusie A-G Mengozzi, Tjebbes, punt 101.

26 Conclusie A-G Mengozzi, Tjebbes, punt 115, 118.

27 Conclusie A-G Mengozzi, Tjebbes, punt 104-107.

28 Conclusie A-G Mengozzi, Tjebbes, punt 113.

29 Conclusie A-G Mengozzi, Tjebbes, punt 131. 
30 Conclusie A-G Mengozzi, Tjebbes, punt 132-134.

31 Conclusie A-G Mengozzi, Tjebbes, punt 137-146.

32 Tjebbes, punt 33; Rottmann, punt 42 en 45.

33 Tjebbes, punt 35-36.

34 Tjebbes, punt 37.

35 Tjebbes, punt 39-41.

36 Tjebbes, punt 42.

37 Tjebbes, punt 45 .

38 Tjebbes, punt 46.

39 Verklaring nr. 2 inzake de nationaliteit van een lidstaat, die door de lidstaten aan de slotakte van het Verdrag betreffende de Europese Unie is gehecht, PbEG 1992, C 191/98; Rottmann, punt 32; Micheletti, punt 10; Tjebbes, punt 30.

40 Tjebbes, punt 31; Grzelczyk, punt 31.

41 G. Davies, 'The Entirely Conventional Supremacy of Union Citizenship and Rights', in: J. Shaw (red.), Has the European Court of Justice Challenged Member State Sovereignty in Nationality Law?, EUI Working Paper RSCAS 2011/62, p. 5.

42 Micheletti, punt 10.

43 Rottmann, punt 42.

44 Conclusie A-G Mengozzi, Tjebbes, punt 113.

45 Conclusie A-G Mengozzi, Tjebbes, punt 113.

46 IGH 6 april 1955, Nottebohm (Liechtenstein/Guatemala), ICJ Reports 1955, p. 4 [1955-1]. Dit arrest van het Internationaal Gerechtshof formuleerde het beginsel dat iedere staat het soevereine recht heeft om te bepalen wie zijn onderdanen zijn en welke criteria hij daarvoor stelt, maar stelde ook een grens aan de juridische betekenis van de toekenning van die nationaliteit in een situatie van diplomatieke bescherming. Omdat er ondanks de toekenning van de nationaliteit van Liechtenstein geen effectieve band bestond tussen Nottebohm en Liechtenstein, kon hij zich in een conflict met

Guatemala, waar hij woonde, niet op diplomatieke bescherming door 
Liechtenstein beroepen.

47 Tjebbes, punt 33-38; Rottmann, punt 51.

48 Rottmann, punt 55-56; Tjebbes, punt 40.

49 D. Kochenov, 'The Tjebbes Fail', European Papers 2019, p. 319336.

5o M. van den Brink, 'Bold, but without Justification', European Papers 2019, p. 409-415.

51 Conclusie A-G Mengozzi, Tjebbes, punt 105-114.

52 In het arrest Tjebbes, punt 40-48, wordt die zinsnede zes keer gebruikt.

53 Tjebbes, punt 44; art. 20 lid 2 sub c jo. 23 VWEU.

54 C. Berneri, Family Reunification in the EU: The Movement and Residence Rights of Third Country National Family Members of EU Citizens, Bloomsbury Publishing 2017, p. 3.

55 Conclusie A-G Mengozzi, Tjebbes, punt 105-114.

56 P.J. Neuvonen, 'EU citizenship and its "very specific" essence:

Rendón Marin and CS', Common Market Law Review 2017, 54(4), p. 1201-1220, p. 1217.

57 HvJ 15 september 2015, zaak C-67/14, Alimanovic, ECLI:EU:C:2015:597, punt 59, cursivering toegevoegd.

58 HvJ 6 oktober 2015, zaak C-650/13, Delvigne, ECLI:EU:C:2015:648.

59 Delvigne, punt 45-49.

60 Conclusie A-G Mengozzi, Tjebbes, punt 64-67, vooral punt 67.

61 Art. 27-28 Richtlijn 2004/38/EG van het Europees Parlement en de Raad van 29 april 2004 betreffende het recht van vrij verkeer en verblijf op het grondgebied van de lidstaten voor de burgers van de Unie en hun familieleden, $P b E U$ 2004, L 158; HvJ 22 mei 2012, zaak C-348/o9, P.I., ECLI:EU:C:2012:300, punt 28; HvJ 8 mei 2018, zaak C-82/16, K.A., ECLI:EU:C:2018:308, punt 92-93; HvJ 13 september 2016, zaak C-165/14, Rendón Marín, ECLI:EU:C:2016:675, punt 8485; HvJ 13 september 2016, zaak C-304/14, CS, ECLI:EU:C:2016:674, punt 40-41. 
62 Tjebbes, punt 46.

63 Zie o.a. P. Van Elsuwege, 'The Phenomenon of Reverse Discrimination: An Anomaly in the European Constitutional Order?', in: L. Rossi en F. Casolari (red.), The EU after Lisbon: Amending or Coping with the Existing Treaties?, Cham: Springer Verlag 2014, p. 162-176; V. Verbist, Reverse discrimination in the European Union: a recurring balancing act, Antwerpen: Intersentia 2016, p. 3-10; A. Tryfonidou, Reverse discrimination in EC law, Alphen aan den Rijn: Kluwer Law International 2009, p. 13-18, 117-118.

64 Tjebbes, punt 41.

65 Tjebbes, punt 41-42.

66 Tjebbes, punt 44 .

(C) Boom juridisch 